\section{参考文献}

1）番場 - 他：臨整外，4, 375, 1969.

2) Minagi : Radiology, 105, 365, 1969.
3) Onji : J.B.J.S., 49-A, 1314, 1967.

4）月本：日整会誌，34,107, 1960 .

5）土屋・他：整外， 21, 768, 1970.

脊髄腫瘍 の 4 例

国立別府病院整形外科

増 田元 彦 - 脇 丸俊 博

直野敬・藤井敏男

内 村 正 英 $\cdot$ 江 崎 正 孝

\title{
Four Cases of the Spinal Cord Tumor
}

By

\author{
M. Masuda, T. Wakimaru, T. Naono,
} T. Fujii, M. Uchimura \& M. Ezaki

Division of Orthopedic Surgery Beppu National Hospital

We report the four cases of the spinal cord tumor which we have experienced recently.

Case 1. female ...... aged fifty was a neurinoma occured in the canda equina.

Case 2. female ...... aged thiry five was a epidermal cyst occured in the nineth thoracic vertebral region.

Case 3. male …. aged fifty seven intramedullary astrocytoma which occured in the region of the fourth thoracic vertebrae.

Case 4. female $\cdots .$. aged eighteen was a meningioma occured in the extradural space of the fourth and fifth thoracic vertebrae.

In the case 1. 2. 4. tumors were operatively almost completely resected, but in the case 3. unable to resect. Consequently in the former, symptom (sensory and motor disturbance) has obviously improved and deminished, but in the latter not improved and deteriorated.

脊髄腫瘍は 1887 年, Gowers と Horsley が最初 に診断し，摘出に成功し，わが国では，1911年，武 谷と三宅が初めて診断し, 摘出に成功して以来, わが 国の文献にみる脊髄腫瘍の報告例は既に数百例を数え える. そしててれらの症例の集計から，脊髄腫瘍の臨 床像, 診断, 治療に関しては, ほぼ完全な考察がなさ れ，それに基づき早期診断，早期摘出が行われるよう になり，良好な予後を期待できるようになった．われ われは最近脊骾腫湯の 4 例を経験したので報告する.

症例 150 才, 主婦.

既往歴 高血圧症

主訴 腰痛, 両下肢痛
現病歴 昭和 44 年 7 月ごろより，歩行時右下肢が 前に出にくいようなととが時々あった. 昭和 45 年 1 月，風邪をひき，咳嗽時腰痛あり，2月に両下肢にき りきりする疼痛あり, 内服薬の投与をうけたが効果が なかった. 3 月上旬, 頸が動きにくくなり, 無理に動 かすと腰より両下肢にかけて疼痛が惹起された. 同時 に下肢の運動, 歩行むぎこちなくなった. 近医に入院

し, 骨盤牽引，ギプス床安静などの 治療で疼痛軽減 し，步行も可能となり退院したが，7月になり再び同 様の症状が再発したので, 7 月 20 日 当院整形外科に 入院した.

入院時所見 食欲不振のためるい馊を認める. 脊柱 
に変形はないが腰椎下部に吒打痛あり, 右坐骨神経 に沿って圧痛あり, 膝蓋腱反射は左右等しく正常だ が, 右アキレス腱反射は減弱し, 右下肢筋に筋萎縮 あり, 右下肢の第 5 腰䯣神経の領域に知覚鈍麻㐫り,

Lasègue 症候右 $45^{\circ}$, 左 $55^{\circ}$ であった. 便秘傾いて いたが，排尿は異常なかった，腰椎穿刺による䯣液所 見では xanthochromia あり, グロブリン反応強陽 性で, Queckenstedt 症候む陽性であった. myelogram では $\mathrm{L}_{4}$ の椎体下縁の右側に陰影の欠損を認め た.

手術所見 $\mathrm{L}_{4}$ 椎体の myelogram に一致した部, 硬膜内に鳩卵大の腫瘍をみ, 馬尾神経の 1 本と密に瘾 着していた. 腫場はその上部 $2 / 3$ は囊腫化し, その被 膜を通して橙黄色半透明の液をみることが出来, 下 $1 / 3$ は光沢ある灰黄色の実質性腫瘍で, 病理組織学的 には神経鞘腫で, 細長い核を有する細長い細胞が束状 に緩やかなうねりをえがき，核の棚状配列むみられ る.

術後経過 順調に経過し, 知覚および下肢筋力は, 術後約 1 力月目にほとんど正常となった.

症例 235 才, 主婦.

主訴 腰部以下の知覚障害, 歩行障害

現病歴 昭和 45 年 12 月, 誘因なく両足先よりシビ レ感が始まり, 程度が重くなると共に次第に上昇し, 昭和 46 年 1 月には腰まで達し, 温冷覚, 痛覚屯鈍くな り，下半身の脱力をきたし，特に左下肢を引きずるよ うになった. 同じ頃より膀胱直腸障害も起とって来 た.

入院時所見 全身状態, 一般的理学検査に異常はな かった. 脊柱の生理的彎曲は減少し, 平背をなす, 背 部に皮虚瘦その他の先天性畸形を認めない. 胸椎部に 吒打痛を認めない，腹壁反射は上は正常, 中および下 は消失している，両膝蓋腱反射，アキレス腱反射は立 進し両側に Babinski 反射陽性で, 左下肢の筋萎縮著 明で，下肢の筋力は $3 \sim 2$ であった. 胸䯣 10 以下に 知覚鈍麻あり, 鼠径部以下に痛覚は脱失する.

髄液所見は初圧 $125 \mathrm{~mm}$ 水柱で, Queckenstedt 症 候陽性, $3 \mathrm{ml}$ の採液で終圧 0 となったが, 水様透明 で, グロブリン反応陰性で細胞数 $2 / 3$ 蛋白量 $30 \mathrm{mg} / \mathrm{dl}$ であった. myelography では腰椎穿刺により上行性 に行い，第 9 胸椎々体のほぼ中央にて騎袷状の停止を みた。

手術所見 第 9 胸椎体の上縁の高さで, 硬膜内䯣外
の腫湯があり脊䯣に対し左前方に存し周囲と瘾着して いるが，神経根とは関係をもたない，摘出腫瘍は棈円 形のウズラ豆大で，光沢のない淡青灰白色で，表面に 腫瑒をとり巻く帯状隆起あり，割面は豆腐から様物質 が同心円状に配列し，組織学的には epidermal cyst であり，囊腫壁は角化扁平上皮より成りその外方に角 化物質をみとめる，毛，腺組織はみられない。

術後経過は良好で, 手術翌日温感の回復の徵あり, 4 日目自然排尿あり, 知覚, 筋力屯次第に回復し, 術 後 5 週目には Babinski 反射も消失し，自由な独立歩 行が可能となった.

症例 357 才, 男.

主訴 下半身の知覚障害之歩行障害

現病歷 昭和 44 年 5 月頃,歩行中左下肢があつれる ような感じがし, 次第に増悪し 10 月には左下肢の運 動がぎこちなくなった．次に右下肢にも同様の症状が おこり，下肢が硬ばり履物がはきにくくなった，昭和 45 年 2 月頃より右下腹部にシビレ感が始まり，次いで 両下肢に拡がり， 3 月には両足蹠に達した. 物につか まらねば歩けなく，排尿には長時間を要するようにな った.

入院時所見 体格中等度, 栄養良好, 心, 肺, 腹部 臟器に異常を認めない，胸椎の生理的後彎は増強して いるが，吒打痛なく，手掌による圧痛を中央以下に認 める。腹壁反射は上, 中, 下共に消失し, 滕蓋腱反射 は両側圥進, 右足揞搦あり, 両側に Babinski 反射陽 性であった．胸髄 6 以下に全知覚の鈍麻を認めた．腰 椎穿刺, Queckenstedt 陽性, 初压 $120 \mathrm{~mm}$ 水柱, 約 $1 \mathrm{ml}$ の採液で液圧 0 となり, xanthochromia を認 める. myelogram では胸椎 4 にて完全な停留像を示 した.

手術所見 胸椎 $3,4,5$ の椎弓を切除すると脊髄は 後方へ著るしく膨隆し, 硬膜を開くと, 蜘蛛膜腔は消 失し, 腫瘍部の脊䯣背側は, 光沢のない灰白色で, 所 々に暗赤色または黒色の出血斑様の小着色巣あり，乙 の部の脊䯣は軟らかく圧迫壊死を抢てしているむの之 思われた．腫瘍は脊髄の前方, 硬膜下にあり, 暗赤色 にみえた．硬膜に小緹切開を加え，腫瘍組織の一部を 採取した，病理組織学的には星状細胞腫で，円形ない し楕円形の核を有する細胞が粗ではあるがほぼ均等に 分布している。

術後テレコバルトを計 $2400 \mathrm{R}$ 照射した. 知覚障害 は増悪し, 下肢の麻㾝も回復するに至らなかった。 
症例 418 才, 女性.

主訴両下肢の疼痛とシビレ感, 歩行障害.

現病歷 来院の 2 年前より冬になる之両下肢のシビ レ感, 疼痛あり, 昭和 45 年 10 月には脱力感が加わ り, 昭和 46 年 2 月 歩行に困難を感じはじめた. 膀胱 直腸障害がある.

入院時所見 全身所見および一般的理学所見に異常 はない. 奉柱は変形はないが, 後屈, 両側屈は制限さ れ, 胸椎 4, 5, 6 の棘突起们打痛を認める. 両滕蓋 腱反射，両アキレス腱反射は共に元進し，Babinski 反射両側陽性, 足揞搦両側陽性であった。 䯣液所見, 初圧 $170 \mathrm{~mm}$ 水性, 採液 $5 \mathrm{ml}$ で終压 0 , Queckenstedt 陽性, 水様透明, グロブリン反応陰性, 細胞数 $4 / 3$, 蛋白量 $60 \mathrm{mg} / \mathrm{dl}$, 胸椎の単純 $\mathrm{X}$ 線像で胸椎 4 の椎弓根像は著るしく縮小している. myelography は腰椎穿刺により上行性に行い, 胸椎 5 の上縁で完全 な停留像を示した。

手術所見 腫湯は胸椎 $3 \sim 6$ 亿亘り, 背側の硬膜外 腔を満し，㹬膜 抢よび脊髄を強く前方に圧排してい た. 春椎管の全横径にわたる腫晹で一部は椎間孔に侵 入していた，腫瘍は淡い黄白色の表面凹凸のある，比 較的硬い腄瘍で, 病理組織学的には, meningothelial meningioma で, 所々に psammoma body を含ん でいる.

術後経過は良好で, 術後 1 週で膀胱直晹障害が, 3 週で運動障害が，4 週で知覚捄よび反射がほとんど正 常に復した.
考按

以上 4 例のうち, 頻度の比較的稀なものは epidermal cyst であり, 1968 年, 立石らの本邦例の集計で は 41 例の 報告がある。そのうち 33 例は馬尾神経部 に， 7 例が胸椎部にそして 1 例が腰椎部に発生してい る. その発生機序は, 先天性組織形成異常ないし外傷 で迷入した表皮組織が, 囊胞を形成したあのとの説が 有力であり, その囊胞壁は表皮類似構造を有し, われ われの例でも囊腫の外方に角化物質, 次に 顆粒細胞 層, 有棘細胞層, 基底細胞層, 結合織層と表皮之同一 の細胞層の配列をみることができた．われわれの例は 穿刺などの外傷をうけるととのない胸椎部であり，外 傷により発生したとは考元難く, 皮膚瘦, 春椎の渏形 などは伴っていないが, 先天性発生異常による先天性 腫湯であると考えられる.

また以上の 4 例を治療しまた多くの報告から硬膜外 腫瘍扔よび硬膜内髄外腫場は, 早期に診断し, 脊䯣が 不可逆性の変化を起こさない早期に摘出すれば, 脊䯣 腫瘍の大半が組織学的に良性腫㗌であるということと あいまって, 良好な予後を期待するととが出来ると言 い得る.しかし䯣内腫場に対する治療は確実なものが なく, 䯣内腫湯としてもっとも頻発する神経膠腫に, 放射線療が有效であったという報告むあるが完全なあ のではなく，われわれの症例にも，テレコバルトが照 射されたが判っきりした効果は認められなかった，従 って䯣内腫瘍に対する確実な手術法の開発は今後の課 題として残されている. 